\title{
KORPUSI NA POTI V ŠOLE: \\ JEZIKOVNOTEHNOLOŠKO IZPOPOLNJEVANJE UČITELJEV
}

\author{
Mojca STRITAR \\ Kaja DOBROVOLJC \\ Trojina, zavod za uporabno slovenistiko
}

Stritar, M., Dobrovoljc, K. (2013): Korpusi na poti v šole: jezikovnotehnološko izpopolnjevanje učiteljev. Slovenščina 2.o, 1 (1): 181-194.

URL: http://www.trojina.org/slovenscina2.o/arhiv/2013/1/Slo2.o_2013_1_10.pdf.

\section{UVOD}

Slovensko društvo za jezikovne tehnologije (SDJT) je $\mathrm{v}$ sodelovanju $\mathrm{s}$ Filozofsko fakulteto v Ljubljani in Trojino, zavodom za uporabno slovenistiko, jeseni 2012 na šolah po Sloveniji izvajalo jezikovnotehnološko izpopolnjevanje učiteljev, ki ga je na podlagi javnega naročila male vrednosti sofinanciralo Ministrstvo za izobraževanje, znanost, kulturo in šport RS ter se neposredno povezuje z Resolucijo o nacionalnem programu za jezikovno politiko 20072011. ${ }^{1}$ Kot je bilo izpostavljeno v obrazložitvi naročila, se večina učiteljev slovenščine $\mathrm{v}$ okviru formalnega izobraževanja še ni srečala $\mathrm{z}$ jezikovnimi viri in orodji, ki so se $\mathrm{v}$ zadnjih letih izkazali za nepogrešljivo kompetenco pri pripravljanju učencev na delovanje v e-okolju. Sem se umeščata poznavanje in uporaba jezikovnih tehnologij, ki deloma zastarel opis jezika, kakršnega nudijo obstoječi normativni priročniki, dopolnjujejo z aktualiziranim opisom sodobne slovenščine.

Projekt, ki ga je vodila predsednica SDJT dr. Špela Vintar, je obsegal

\footnotetext{
${ }^{1}$ 6. cilj (ukrep f) in 10. cilj (ukrepi a-f). Resolucija je veljala za obdobje 2007-2011, vendar je nov, aktualnejši dokument še vedno $\mathrm{v}$ fazi priprave, prim.: http://www.arhiv.mk.gov.si/si/delovna_podrocja/slovenski_jezik/predstavitev_podrocja/pripra va_resolucije_za_nacionalni_program_za_jezikovno_politiko_20122016/.
} 
vsebinsko in organizacijsko pripravo izobraževanja, s katerim bi usposobili predvsem srednješolske učitelje slovenščine za osnovno delo $\mathrm{z}$ jezikovnotehnološkimi viri in orodji, izvedbo tridesetih osemurnih seminarjev in končno evalvacijo. Vsi našteti vidiki so podrobneje predstavljeni $\mathrm{v}$ nadaljevanju.

\section{VSEBINA IZPOPOLNJEVANJA}

Vsebinsko je izpopolnjevanje zasnovala skupina strokovnjakov, ki so imeli teoretične in raziskovalne, pa tudi aplikativne in pedagoško-andragoške izkušnje s posameznimi jezikovnotehnološkimi področji ter so poleg tega $\mathrm{v}$ kratkem časovnem roku, ki je bil na voljo, lahko pripravili potrebno gradivo: Kaja Dobrovoljc, dr. Iztok Kosem, dr. Nataša Logar Berginc, dr. Mojca Stritar in dr. Špela Vintar. S komentarji, nasveti in izkušnjami so pri pripravi sodelovali še dr. Irena Krapš Vodopivec, dr. Tadeja Rozman, dr. Ana Zwitter Vitez in izvajalci izobraževanj.

Izpopolnjevanje je bilo razdeljeno na dva vsebinska sklopa (Tabela 1).

\begin{tabular}{|c|c|c|}
\hline Sklop & Tema & $\begin{array}{c}\text { Trajanje } \\
\text { (v šolskih urah) }\end{array}$ \\
\hline \multirow[t]{7}{*}{1.} & Uvod: jezikovni opis in jezikovna norma & 0,25 \\
\hline & SSKJ in SP 2001 & 0,25 \\
\hline & Splošni korpusi slovenščine & 0,5 \\
\hline & Delo s korpusom Gigafida: enostavno iskanje & 1 \\
\hline & Delo s korpusom Gigafida: napredno iskanje & 1 \\
\hline & $\begin{array}{l}\text { Delo s korpusom Gigafida: zgodovina, iskanje po } \\
\text { seznamih }\end{array}$ & 0,5 \\
\hline & Slovenski oblikoslovni leksikon SLOLEKS & 0,5 \\
\hline \multirow[t]{3}{*}{2.} & Ponovitev dela s korpusom Gigafida & 0,5 \\
\hline & Korpus GOS & 1 \\
\hline & Viri za pouk književnosti & 0,5 \\
\hline
\end{tabular}




\begin{tabular}{|l|c|}
\hline Dopolnilna orodja in viri za slovenščino & 0,5 \\
\hline Večjezični viri in tehnologije & 1 \\
\hline Sklep, razprava in evalvacija & 0,5 \\
\hline Skupno trajanje izobraževanja & $\mathbf{8}$ \\
\hline
\end{tabular}

Tabela 1: Teme jezikovnotehnološkega izpopolnjevanja.

Prvi sklop je izhajal iz tem, ki naj bi jih udeleženci predvidoma dobro poznali. $\mathrm{V}$ njem je bila predstavljena vloga obstoječih jezikovnih priročnikov pri jezikovnem opisu in normiranju, pri čemer so bila s primeri obstoječih jezikovnih priročnikov osvetljena šibka mesta trenutne norme in kodifikacije. Nato so bili predstavljeni jezikovni korpusi na splošno, milijardni pisni korpus Gigafida $^{2}$ in referenčni korpus Kres. ${ }^{3}$ Večina prvega sklopa je bila namenjena praktičnemu delu z vmesnikom za dostop do obeh korpusov. Udeleženci so po korakih spoznavali različne funkcionalnosti (enostavno in napredno iskanje, filtre, iskanje po okolici ter po seznamih), jih sproti preizkušali s kratkimi vajami in jih komentirali predvsem z vidika uporabnosti pri šolskem pouku. Delo je bilo popestreno s prikazom delovanja oblikoslovnega označevalnika ${ }^{4}$ in Slovenskega oblikoslovnega leksikona.5 Udeleženci so dobili tudi dodatne naloge za delo s korpusoma, ki so se nanašale na pravopis, besedišče, oblikoslovje, skladnjo in frazeologijo.

Drugi sklop se je začel z motivacijsko nalogo, s katero so udeleženci ponovili nekatere možnosti iskanja po korpusih Gigafida oziroma Kres. Predstavitev govornega korpusa GOS$^{6}$ je bila nekoliko krajša, ker so bili udeleženci že seznanjeni $\mathrm{z}$ delovanjem korpusnega vmesnika, in se je osredotočala predvsem na specifike govornega korpusa (predvajanje zvočnih posnetkov,

\footnotetext{
2 http://www.gigafida.net/

3 http://www.korpus-kres.net/

4 http://oznacevalnik.slovenscina.eu/

5 http://www.slovenscina.eu/sloleks

6 http://www.korpus-gos.net/
} 
posebnosti v filtrih, standardizirani ter pogovorni zapis). V nadaljevanju so bili prikazani viri za pouk književnosti: korpus Nova beseda7 (s poudarkom na iskanju po delih posameznih avtorjev), slovenski leposlovni klasiki na spletu (WikiVir8 in različni iskalniki) ter Jezikovni viri starejše slovenščine9 (digitalna knjižnica, korpus in slovar). Med ostalimi viri in orodji za slovenščino sta bila kratko predstavljena korpus Šolar ${ }^{10}$ in slovenski pomenoslovni leksikon sloWNet. ${ }^{11}$ Zadnji tematski del je bil namenjen večjezičnim virom in orodjem: vzporednemu korpusu Evrokorpus, ${ }^{12}$ slovarskemu portalu Termania ${ }^{13}$ in strojnemu prevajanju besedil, v okviru katerega so udeleženci preizkusili ter komentirali spletna prevajalnika Presis ${ }^{14}$ in Google Translate. ${ }^{15}$ Ob zaključku je zgoščenemu pregledu obravnavanih virov sledila vodena razprava o možnih načinih njihove uporabe pri pouku in drugod.

Gradivo za izpopolnjevanje smo pripravili kot PowerPointovo predstavitev z več kot 140 prosojnicami, ki so pokrivale vsa vsebinska področja in so vključevale več kot 50 nalog, primerov iskanj ipd. Vsebine smo zasnovali ekstenzivno, tako da bi bile lahko tiste, ki bi se izkazale za manj relevantne, ob izvedbi seminarja izpuščene. Razlage so bile postopne, praviloma je bil vsak korak na svoji prosojnici. Ker ob pripravi brez pilotske skupine ni bilo mogoče natančno predvideti, kako nazorne in počasne naj bi bile razlage med seminarjem, so bile narejene po načelu najšibkejšega člena tako, da bi jih lahko razumeli in jim sledili tudi najmanj računalniško spretni udeleženci.

Prosojnice smo izdelali tudi v različici, namenjeni izvajalcem seminarja. V njej

\footnotetext{
7 http://bos.zrc-sazu.si/s_beseda.html

8 http://sl.wikisource.org/wiki/Wikivir:Slovenska_leposlovna_klasika

9 http://nl.ijs.si/imp/

$10 \mathrm{http}: / /$ www.korpus-solar.net/

11 http://nl.ijs.si/slowtool/

12 http://evrokorpus.gov.si/

13 http://www.termania.net/

$14 \mathrm{http}: / /$ presis.amebis.si/prevajanje/

15 http://translate.google.com/
} 
so bila pri vsakem koraku razlage pojasnila avtorjev gradiva, kako naj bi ta potekala. Pripravljena je bila še različica za izvedbo seminarja brez povezave na splet, v kateri so bile informacije, ki bi jih bilo treba prikazati na spletu, vključene kot zaslonski posnetki.

\section{ORGANIZACIJA IZPOPOLNJEVANJA}

Vzporedno s pripravo gradiv je potekala organizacijska priprava seminarjev, ki jo je vodila Kaja Dobrovoljc. K sodelovanju smo povabili predvsem učitelje slovenščine na gimnazijah in srednjih tehniških šolah, pri čemer smo si prizadevali zagotoviti čim večjo regijsko uravnoteženost. Na naše vabilo sta se pozitivno odzvali dve tretjini kontaktiranih šol, ostalim pa zaradi kratke časovne omejitve za izvedbo projekta, ${ }^{16}$ ki jo je predvidel financer, kljub pripravljenosti posameznih učiteljev ni uspelo uskladiti natrpanih urnikov. Večina ravnateljev in vodij aktivov - tudi na šolah, ki so sodelovanje zavrnile - je še posebej pohvalila dejstvo, da je bilo izobraževanje brezplačno in da smo ga izvajali v računalniških učilnicah na samih šolah.

Za sodelovanje se je odločilo 29 srednjih in ena osnovna šola, ki so prikazane na Sliki 1. ${ }^{17}$ Večina šol se je odločila za dva ločena štiriurna sklopa, med

\footnotetext{
16 Vseh 30 izobraževanj smo izvedli v obdobju od 25. septembra do 19. novembra 2012.

17 Biotehniški center Naklo - Srednja šola; Ekonomska šola Novo mesto; Gimnazija Bežigrad, Ljubljana; Gimnazija Brežice; Gimnazija Franca Miklošiča Ljutomer; Gimnazija in ekonomska srednja šola Trbovlje; Gimnazija in srednja šola Rudolfa Maistra Kamnik; Gimnazija Jožeta Plečnika Ljubljana; Gimnazija Kočevje; Gimnazija Koper; Gimnazija Kranj; Gimnazija Ledina, Ljubljana; Gimnazija Murska Sobota; Gimnazija Nova Gorica; Gimnazija Novo mesto; Gimnazija Poljane; Gimnazija Ptuj; Gimnazija Šiška, Ljubljana; Gimnazija Škofja Loka; Gimnazija Vič, Ljubljana; I. gimnazija v Celju; II. gimnazija Maribor; Osnovna šola Majde Vrhovnik, Ljubljana; Prva gimnazija Maribor; Srednja šola Josipa Jurčiča Ivančna Gorica; Srednja šola Veno Pilon Ajdovščina; Škofijska gimnazija Vipava; Šolski center Novo mesto - Srednja elektro šola in tehniška gimnazija; Šolski center Postojna; Tehniški šolski center Nova Gorica - Elektrotehniška in računalniška šola. Izbrana osnovna šola je bila k sodelovanju povabljena proti koncu projekta, deloma zaradi zapolnitve prostih terminov, deloma pa kot pilotski preizkus za morebitna nadaljnja izobraževanja tudi na osnovnih šolah.
} 
katerima je običajno minil en teden, na petih šolah pa smo celotni osemurni seminar izvedli v enem samem dnevu. Vse sodelujoče šole so se ob prijavi strinjale $\mathrm{s}$ tem, da v primeru prostih mest, ki so bila omejena s številom računalnikov v računalniški učilnici, $\mathrm{k}$ udeležbi povabimo tudi učitelje drugih srednjih ali osnovnih šol. Udeleženci so ob koncu seminarja dobili potrdilo o udeležbi in potrebno dokumentacijo, ki jo lahko uveljavljajo pri napredovanju v pedagoške nazive.

Vseh seminarjev po Sloveniji se je skupaj udeležilo 233 udeležencev, od tega 210 srednješolskih in 21 osnovnošolskih učiteljev ter dva udeleženca z drugih izobraževalnih ustanov. 179 udeležencev se je izpopolnjevalo na šolah, kjer so zaposleni, 54 pa se jih je izobraževanjem na teh šolah pridružilo po naknadnem povabilu drugim učiteljem v kraju oz. regiji. Izpopolnjevanje je bilo namenjeno predvsem učiteljem slovenščine (teh je bilo 210), k udeležbi pa

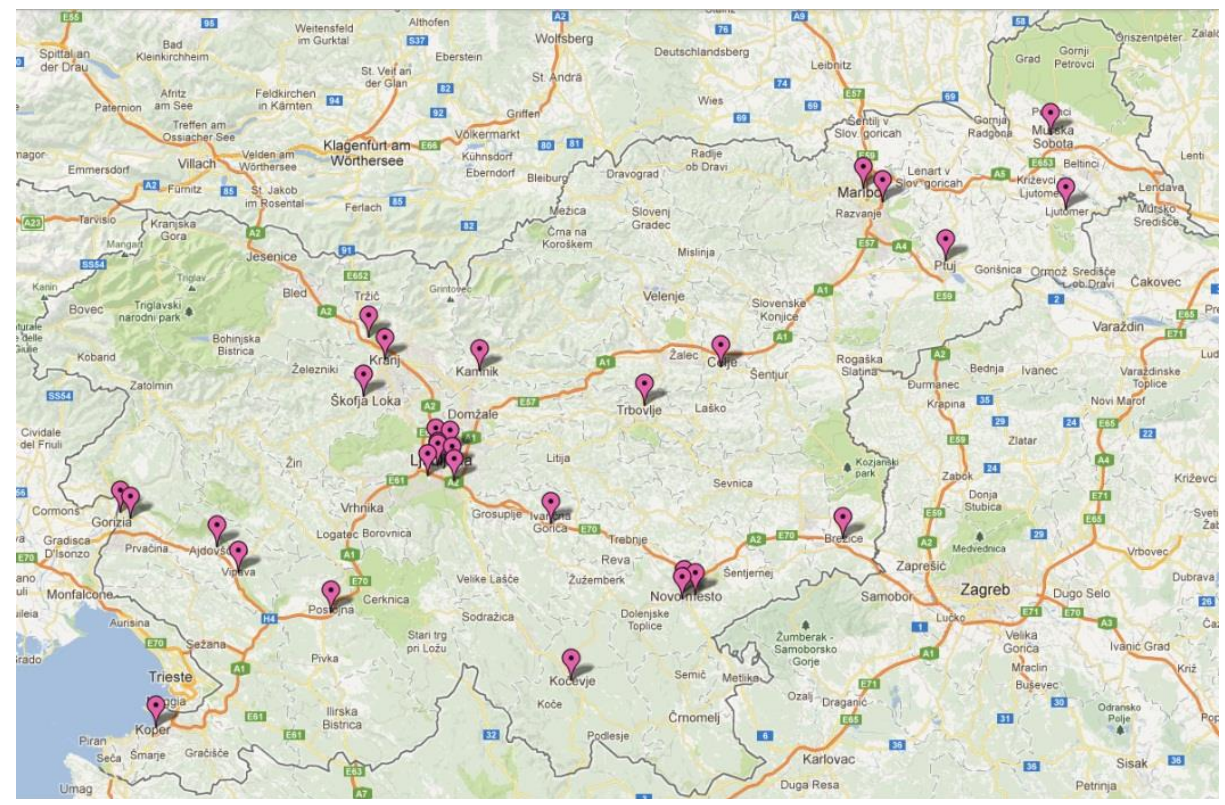

Slika 1: Zemljevid vseh lokacij izobraževanja.

so bili vabljeni tudi učitelji drugih vsebin, med katerimi so prevladovali učitelji tujih jezikov in informatike ter knjižničarji (skupaj 23). 
Vsako izpopolnjevanje je izvajal eden od osmih izkušenih predavateljev, ki se poklicno ukvarjajo $\mathrm{z}$ jezikovnimi tehnologijami in so tudi sicer dejavni $\mathrm{v}$ izobraževanju: Kristina Bizjak, dr. Darja Fišer, Jure Janet, dr. Iztok Kosem, dr. Tamara Mikolič Južnič, dr. Tadeja Rozman, dr. Mojca Stritar in mag. Jernej Vičič. Izhajali so iz vnaprej pripravljenega gradiva, ki pa so ga prilagodili glede na lastne želje in specifike udeležencev: dodali ali izpustili primere, naloge ali vsebinske sklope, dodali uvodno motivacijo, pospešili tempo izvajanja ipd. Zaradi tehničnih težav na strežniku korpusa Gigafida v času trajanja projekta je večina izvajalcev prešla na uporabo korpusa Kres, tako da so temu primerno spremenili prosojnice. Delo je bilo večinoma frontalno, udeleženci so z delom na svojem računalniku sledili izvajalcu, ki je prikazoval vsebino prek projektorja oziroma interaktivne table. Po želji so delali v dvojicah ali skupinah, predavateljski način dela pa se je nenehno prepletal s skupno razpravo. Po posameznih izvedenih seminarjih so izvajalci svoja mnenja, izkušnje in predloge izmenjevali preko internega e-poštnega seznama ter tako aktivno sooblikovali pripravljeni učni načrt.

Projekt je imel svojo spletno stran, ${ }^{18}$ na kateri so udeleženci dobili osnovne informacije in razpored izpopolnjevanj, gradivo ${ }^{19}$ ter povezave do predstavljenih jezikovnih virov in orodij. Prizadevamo si, da bi stran živela tudi po zaključku projekta in se nenehno posodabljala z obvestili o novostih $\mathrm{s}$ področja jezikovnih tehnologij ter njihovem prenosu v pedagoški proces.

\section{IZKUŠNJE UDELEŽENCEV}

Ob koncu vsakega izvedenega seminarja smo učitelje prosili za povratno informacijo. Anonimno anketo, objavljeno na projektni spletni strani,20 je izpolnilo 145 učiteljev (62 \% vseh udeležencev). V njej smo jih spraševali, kako

\footnotetext{
18 http://www.sdjt.si/ucitelji/

19 Na spletni strani so bile dostopne skupne prosojnice, ki pa so jih posamezni izvajalci pred izvedbo v šolah prilagodili in jih prikazovali vsebinsko ali grafično spremenjene. Udeleženci so bili na to opozorjeni.

20 http://www.sdjt.si/ucitelji/vprasalnik
} 
zadovoljni so z različnimi vidiki izpopolnjevanja. Kot je razvidno z grafičnih prikazov na Slikah 2 in 3, so bili učitelji z vsebino in izvedbo seminarjev zelo zadovoljni, saj je več kot 92 \% udeležencev vse naštete vidike ocenilo z oceno 4 ali 5 (zadovoljen oz. zelo zadovoljen).

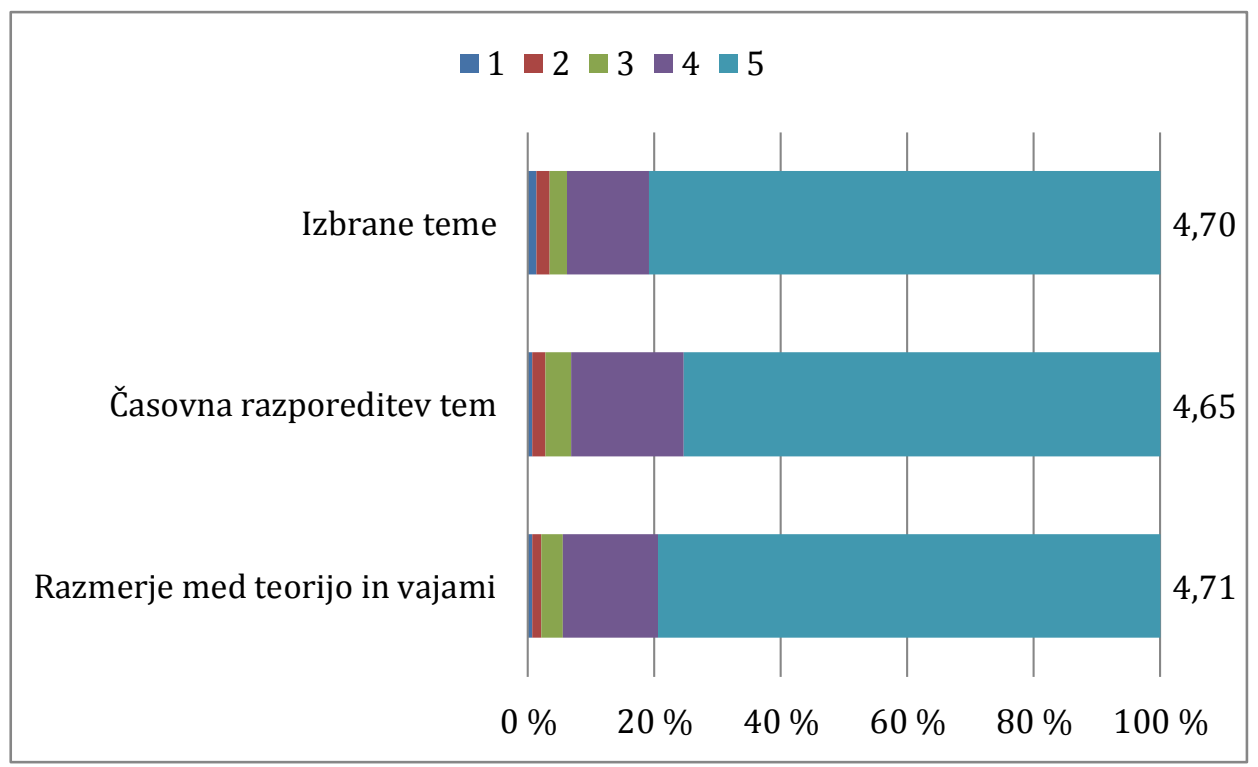

Slika 2: Ocena zadovoljstva z vsebino izpopolnjevanja, pri čemer ocena 1 pomeni »zelo nezadovoljen «, ocena 5 pa »zelo zadovoljen «.

Nekoliko bolj razpršene so ocene uporabnosti posameznih vsebinskih sklopov (Slika 4). Učiteljem so se predstavljeni viri in orodja zdeli najbolj uporabni za lastno strokovno delo ali zanimanja, nekoliko manj za samostojno delo učencev in dijakov, najmanj pa za delo v razredu (povprečna ocena 3,68). Pri vprašanju odprtega tipa glede tega, kateri vsebinski sklop se jim je zdel najbolj uporaben za delo z učenci oz. dijaki v razredu, so izpostavljali predvsem delo z besedilnimi korpusi, Slovenski oblikoslovni leksikon, vire za pouk književnosti (vključno z Jezikovnimi viri starejše slovenščine) in različne spletne slovarje. 


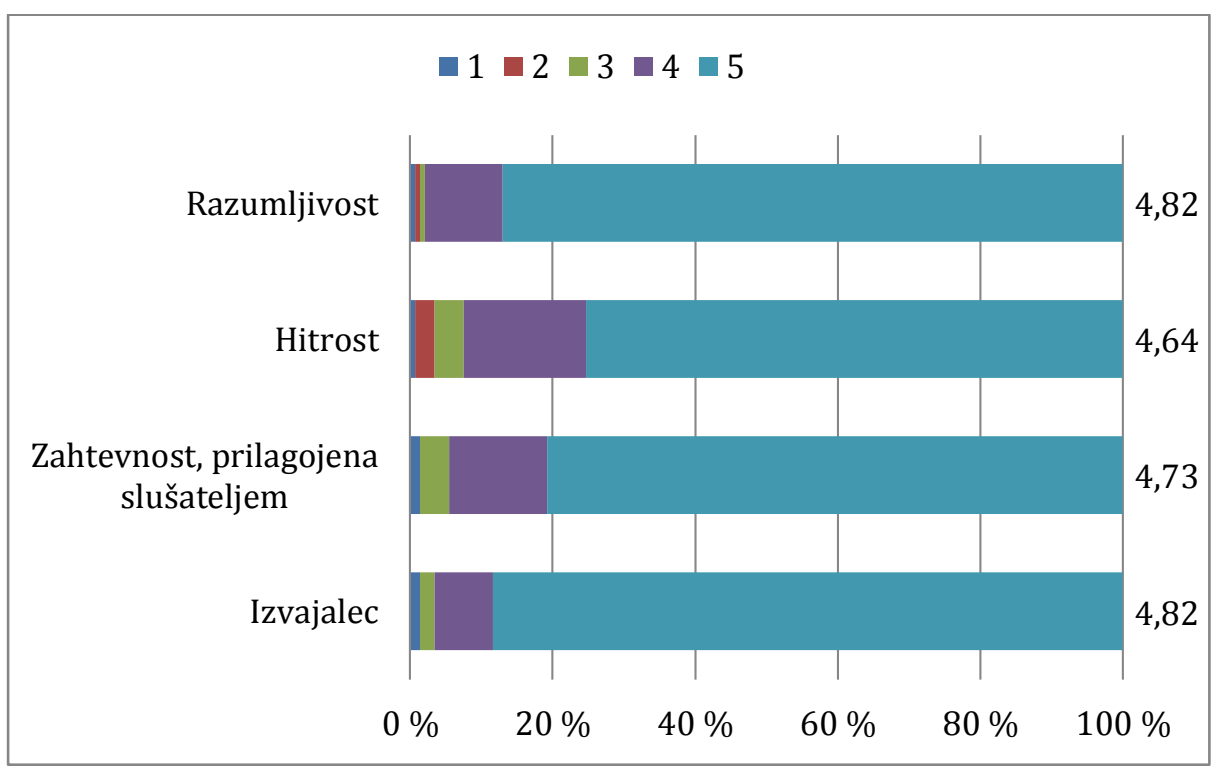

Slika 3: Ocena zadovoljstva z izvedbo izobraževanja, pri čemer ocena 1 pomeni »zelo nezadovoljen«, ocena 5 pa »zelo zadovoljen«.

Nekoliko nižje ocene uporabnosti za delo v razredu so bile pričakovane, saj morajo uporabniki večino predstavljenih virov najprej dobro poznati za lastno delo, da jih lahko didaktično uporabijo z učenci. Manjša neposredna uporabnost je verjetno tudi posledica strogo predpisane normativnosti, ki, sodeč po razpravah $\mathrm{z}$ udeleženci, še vedno zelo zaznamuje šolski pouk slovenščine.

Pri vprašanju, kaj jim je bilo še posebej všeč, so udeleženci izpostavljali predvsem delo izvajalcev (nazornost in sistematičnost podajanja vsebin, prilagodljivost, vzdušje), količino praktičnih vaj ter posledično uporabnost oziroma konkretnost predstavljenih vsebin. Veliko udeležencev je poudarilo, da so z izobraževanjem izgubili strah pred spoznavanjem novih tehnologij, saj se je njihova uporaba izkazala za enostavnejšo in koristnejšo, kot so pričakovali. 


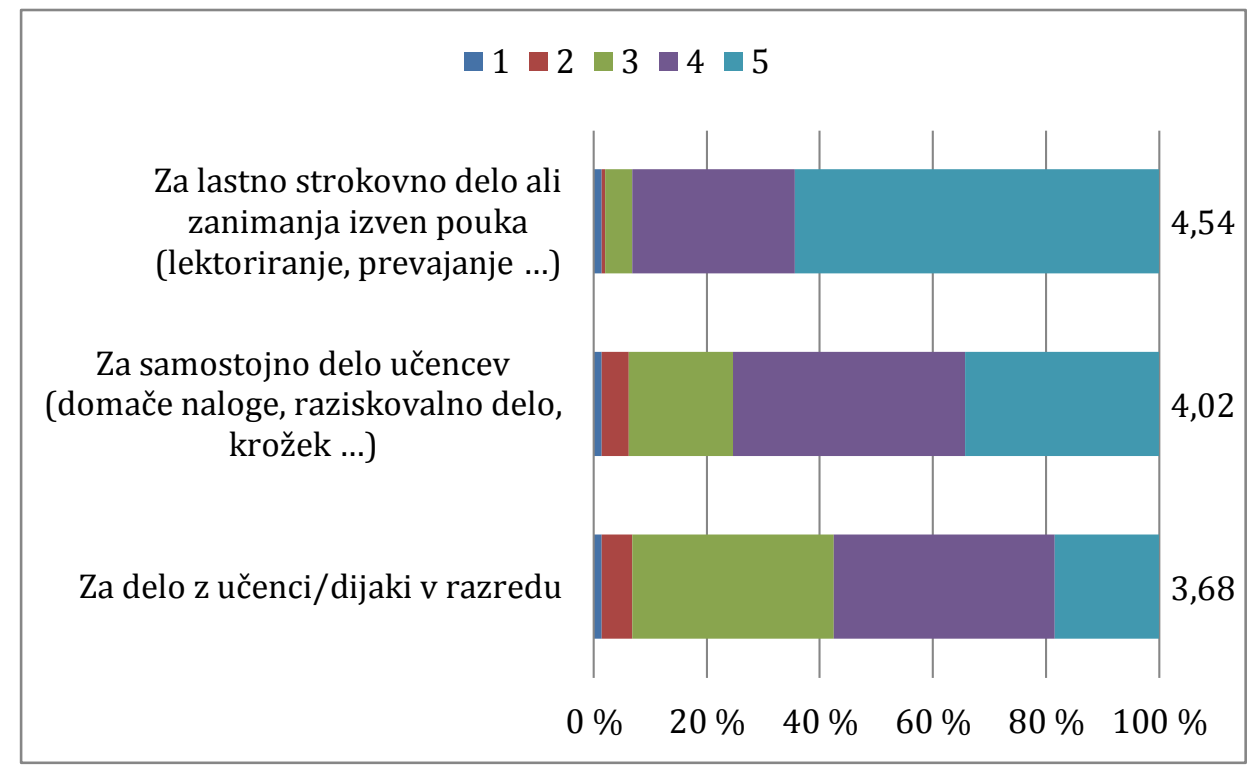

Slika 4: Ocena uporabnosti izobraževanja, pri čemer ocena 1 pomeni "povsem neuporabno«, ocena 5 pa »zelo uporabno«.

Na koncu smo udeležence povprašali še, kaj jim ni bilo všeč in ali so kaj pogrešali. Teh odgovorov je bilo precej manj, v njih pa so učitelji še enkrat izrazili željo, da bi bilo več poudarka namenjenega konkretnemu prenosu vsebin v razred. Preostali, majhen delež udeležencev so motili časovna umestitev izobraževanj v popoldanski čas, kar je bilo sicer v pristojnosti samih šol, prehiter ali prepočasen tempo in prevelika količina podatkov.

\section{IZKUŠNJE IZVAJALCEV}

Čeprav so izvajalci imeli seminarje na različnih šolah po vsej Sloveniji, so bile izkušnje vseh v glavnem dobre. Udeleženci so pred tem imeli malo stika z jezikovnimi tehnologijami in so se celo bali, da bodo zanje prezapletene, a so jih z aktivnim preizkušanjem hitro usvojili in, kot je bilo razvidno tudi iz anket, bili nad njihovo uporabnostjo ter enostavnostjo večinoma opazno navdušeni. 
Kot pozitivno so izvajalci seminarjev izpostavili:

- visoko motiviranost večine udeležencev, odprtost za spoznavanje novih jezikovnih virov in aktivno sodelovanje;

- Široko zasnovano in časovno dobro razporejeno gradivo, ki je omogočalo prilagajanje, izpuščanje ali dodajanje vsebin ter zaradi podrobnih razlag v komentarjih od izvajalcev ni zahtevalo dolgotrajnejših priprav;

- postopnost gradiva, tako da so mu lahko sledili tudi računalniško najmanj spretni udeleženci, hitrejši in bolj motivirani pa so medtem lahko iskali odgovore na druga vprašanja;

- prilagojenost vsebin potrebam učiteljev, kar so udeleženci večkrat poudarili; posebej dobro sprejete so bile naloge, ki so se povezovale s konkretno prakso v razredu, z uvodoma izpostavljenimi neskladji med normo in rabo, $\mathrm{z}$ aktualnimi družbeno-političnimi dogajanji ali $\mathrm{z}$ lokalnimi posebnostmi;

- priložnost za obširne, poglobljene in živahne pogovore o za učitelje relevantnih slovenističnih temah, predvsem v uvodnem delu seminarja;

- prilagodljivost tehnične podpore pri večini jezikovnih virov (odzivna podporna služba za korpuse Gigafida, Kres in GOS; med trajanjem projekta je bil na pobudo udeležencev pripravljen nov konkordančnik za projekt Jezikovni viri starejše slovenščine ipd.) in dobra logistična podpora projekta;

- možnost prostega dostopa do vseh prikazanih jezikovnih virov;

- gostoljubnost večine šol, na kateri so potekala izobraževanja, ter večinoma dobro delujoča strojna in programska oprema v računalniških učilnicah;

- na seminarju so aktivno sodelovali tudi učitelji z osnovnih šol ali drugih predmetov in pozitivno komentirali njegovo uporabnost.

V splošnem je bilo med seminarjem zaznati največ pozitivnih odzivov na 
slovarje in digitalno knjižnico $\mathrm{v}$ Jezikovnih virih starejše književnosti, Slovenski oblikoslovni leksikon (v katerem pa so bile problematične v času izvajanja seminarja nedelujoče povezave na konkordance $v$ Gigafidi in nezanesljivi podatki o številu pojavitev v tem korpusu kot posledica strojnega označevanja) ter Spletni slovar slovenskega jezika, ${ }^{21}$ ki so ga nekateri izvajalci naknadno vključili v gradivo. Kljub manjši neposredni uporabnosti so udeleženci z zanimanjem sprejemali razlago o oblikoslovnem označevalniku in vpogled v ozadje označevanja besedil uspešno osmislili kot pojasnilo napak pri označevanju.

Nekoliko manj prepričljivo je bilo prikazovanje pomenoslovnega leksikona sloWNet, verjetno tudi zato, ker so ga izvajalci manj poznali in ga zato težje predstavljali. Nekaj pomislekov so med izvajalci seminarjev vzbudili še naslednji vidiki:

- nestabilno delovanje korpusa Gigafida v času izvajanja seminarja, zaradi katerega je večina izvajalcev uporabljala le korpus Kres ali pa oba in to izkoristila za prikazovanje razlik med obema;

- hrošči v nekaterih virih (npr. pri naprednem iskanju v korpusu GOS, nepredvajanje zvočnih posnetkov iz GOS-a v brskalniku Firefox);

- na spletu neizbežno nedelovanje nekaterih povezav na literarna dela, dosegljiva v iskalnikih po slovenski književnosti;

- ker gradivo zaradi časovnih omejitev pri organizaciji seminarja ni bilo vnaprej preizkušeno, je bilo treba določene vaje ali vsebine naknadno spremeniti;

- uvodni teoretični del je bil sicer nujen, a se je izkazal za nekoliko preabstraktnega in predolgega;

- računalniško manj spretni udeleženci so imeli težave $\mathrm{z}$ vtipkavanjem spletnih naslovov posameznih virov v spletni brskalnik;

${ }^{21}$ http://www.slovenscina.eu/spletni-slovar 
- $\quad$ vaje bi se lahko še bolj navezovale na konkretne težave, s katerimi se pri delu z učenci srečujejo učitelji;

- nekaj seminarjev je bilo izvedenih tako, da sta oba sklopa potekala $\mathrm{v}$ enem dnevu, kar je bilo demotivirajoče za udeležence in izčrpavajoče tudi za izvajalca;

- slaba organizacija izobraževanja na nekaj šolah, zamujanje ali predčasno odhajanje nekaterih udeležencev.

\section{SKLEP}

Seminar je bil zasnovan predvsem z mislijo na to, kako bi lahko učitelji nove jezikovne vire uporabili pri pouku jezika, književnosti ali drugem delu z jezikom, ne da bi jih to časovno dodatno obremenilo. Le $\mathrm{z}$ visoko informativnostjo in enostavno uporabnostjo jih namreč ti viri lahko prepričajo, da bodo postali njihovi redni uporabniki in jih bodo v idealnem primeru začeli tudi širiti med dijake ter učence.

Glede na uspešnost izvedenega projekta želimo s tovrstnim izpopolnjevanjem nadaljevati. Nadgradnja spletne strani projekta bi omogočala, da bi učitelji poleg gradiv in povezav lahko uporabljali še forum, na katerem bi izmenjevali izkušnje iz razreda, postavljali vprašanja strokovnjakom ali razpravljali o jezikovnih vprašanjih. Izpopolnjevanja želimo izvesti na vseh zainteresiranih šolah, tako osnovnih kot srednjih, pa tudi za nejezikoslovce ali učitelje tujih jezikov. V nadaljnja izpopolnjevanja bi bilo smiselno vključiti bolj poglobljeno rabo manjšega števila virov. Zanimivo bi bilo izvesti izobraževanje za dijake, naslednji korak, željo po katerem so izrazili tudi učitelji, pa je priprava gradiva za izvedbo konkretnega pouka s korpusi. Z vključitvijo tovrstnih seminarjev v katalog izobraževanj ali seminarjev za e-kompetenčnega učitelja bi jim večjo veljavo dalo tudi pristojno ministrstvo. Eden od najvišjih in s tem najtežje dosegljivih ciljev pa bi bila vključitev korpusnega pogleda na jezik $\mathrm{v}$ maturitetno ocenjevanje; ne nazadnje se mnogi učitelji sklicujejo prav na maturo kot na razlog za vztrajanje pri pogosto (pre)ozko zamejeni normi. 
To delo je ponujeno pod licenco Creative Commons: Priznanje avtorstvaDeljenje pod enakimi pogoji 2.5 Slovenija.

This work is licensed under the Creative Commons Attribution ShareAlike 2.5 License Slovenia.

http://creativecommons.org/licenses/by-sa/2.5/si/

(C) (1) (-) 